\title{
Accessory Renal Arteries; Clinical Features and Prognosis in Hypertensive Children
}

\author{
Aksesuar Renal Arterli Hipertansif Çocuklarda Klinik Özellikler ve \\ Prognoz
}

\author{
Zehra AYDIN¹, Yasin Adem KOKSOY¹, Adalet Elcin YILDIZ², Altan GUNES²,Umut Selda BAYRAKCI ${ }^{1,3}$
}

\author{
1Department of Pediatric Nephrology, Ankara Child Health and Diseases Hematology Oncology Training and Research Hospital, \\ Ankara, Turkey \\ 2Department of Pediatric Radiology, Ankara Child Health and Diseases Hematology Oncology Training and Research Hospital, \\ Ankara, Turkey \\ ${ }^{3}$ Department of Pediatric Nephrology, Ankara Yildirim Beyazit University Faculty of Medicine, Ankara, Turkey
}

\begin{abstract}
Objective: Accessory renal arteries may be related to the risk of renovascular hypertension. This study aims to evaluate the clinical course of accessory renal arteries in children with hypertension. We also aimed to compare renal function tests, blood pressure loads, frequency of end-organ damage, and prognosis of hypertensive patients who had detected single and accessory renal artery with Magnetic Resonance Angiography.

Material and Methods: From 01 January 2015 to 31 December 2017 medical records of hypertensive patients were retrospectively reviewed and patients who had been evaluated with Magnetic Resonance Angiography for differential diagnosis of renovascular hypertension were selected. Hypertensive patients with single renal arteries and those who had accessory arteries were compared in the terms of findings Doppler Ultrasound, blood pressure load, and presence of end-organ damage, laboratory investigations, treatment modalities, and prognosis.

Results: Of 49 hypertensive patients who underwent Magnetic Resonance Angiography, 26 (51\%) showed accessory renal arteries. Despite the normal Doppler Ultrasound, 13 patients were found to have accessory renal artery with Magnetic Resonance Angiography. There was no significant difference between blood pressure load, and laboratory investigations between the patients with single renal arteries and those who had accessory renal arteries. The frequency of end-organ damage was also similar between both groups at the end of follow-up period as well as the number of medications.
\end{abstract}

Conclusion: Magnetic Resonance Angiography is more successful than Doppler Ultrasound to detect accessory renal artery. It seems that the presence of accessory renal arteries does not affect the prognosis of the disease.

Key Words: Children, Hypertension, Renal artery

öz

Amaç: Aksesuar renal arterler, renovasküler hipertansiyon ile ilişkili olabilir. Bu çalışma, hipertansiyonlu çocuklarda aksesuar renal arterlerin klinik seyrini değerlendirmeyi amaçlamaktadır. Ayrıca, Manyetik Rezonans Anjiyografi ile tek ve aksesuar renal arter tespit edilen hipertansif çocuk hastaların, böbrek fonksiyon testleri, kan basıncı yükleri, hedef organ hasar sıklığı ve prognozunu karşılaştırmayı amaçladık.

(1)

AYDIN Z : 0000-0002-9605-725X KOKSOY YA : 0000-0003-4814-759X $\begin{array}{ll}\text { YILDIZ AE } & : 0000-0001-7208-8097 \\ \text { GUNES A } & : 0000-0002-0365-1218\end{array}$ BAYRAKCI US : 0000-0002-5301-2617

Conflict of Interest / Çıkar Çatışması: On behalf of all authors, the corresponding author states that there is no conflict of interest.

Ethics Committee Approval / Etik Kurul Onayr: This study was conducted in accordance with the Declaration of Helsinki and was approved by the Clinical Research Ethics Committee No.2, Ankara City Hospital (07.04.2021-E2-21-311).

Contribution of the Authors / Yazarların katkısı: AYDIN Z: Planning methodology to reach the Conclusions, Taking responsibility in patient follow-up, collection of relevant biological materials, data management and reporting, execution of the experiments, Taking responsibility in logical interpretation and conclusion of the results, Taking responsibility in necessary literature review for the study, Taking responsibility in the writing of the whole or important parts of the study, Reviewing the article before submission scientifically besides spelling and grammar. KOKSOY YA: Taking responsibility in patient follow-up, collection of relevant biological materials, data management and reporting, execution of the experiments, Taking responsibility in necessary literature review for the study. YILDIZ AE: Taking responsibility in logical interpretation and conclusion of the results. GUNES A: Taking responsibility in logical interpretation and conclusion of the results. BAYRAKCI US: Constructing the hypothesis or idea of research and/or article, Planning methodology to reach the Conclusions, Organizing, supervising the course of progress and taking the responsibility of the research/study, Taking responsibility in necessary literature review for the study, Taking responsibility in the writing of the whole or important parts of the study, Reviewing the article before submission scientifically besides spelling and grammar.

How to cite / Atıf yazım şekli : Aydin Z, Koksoy YA, Yildiz AE, Gunes A and Bayrakci US. Accessory Renal Arteries; Clinical Features and Prognosis in Hypertensive Children. Turkish J Pediatr Dis 2022;16:259-263.

Additional information / Ek bilgi: This article has been presented at the 2019 Turkey Pediatric Nephrology congress as a poster. 
Gereç ve Yöntemler: Hastanemize 01 Ocak 2015- 31 Aralık 2017 yılları arasında başvuran hipertansif çocuk hastaların tıbbi kayıtları retrospektif olarak incelendi ve renovasküler hipertansiyon șüphesi ile Manyetik Rezonans Anjiyografi ile değerlendirilen hastalar belirlendi. Aksesuar renal arterli ve tek renal arterli hipertansif çocuk hastaların laboratuvar tetkikleri, Doppler Ultrasonografi, kan basıncı yükleri, hedef organ hasarı varlığı, tedavi modaliteleri ve prognozları karşılaştırıldı.

Bulgular: Manyetik Rezonans Anjiyografi yapılan 49 hipertansif hastadan 26’sında (\%51) aksesuar renal arterler görüldü. Normal Doppler Ultrasonografi'ye rağmen, 13 hastada Manyetik Rezonans Anjiyografi ile aksesuar renal arter olduğu bulundu. Bununla birlikte, aksesuar renal arterleri olan hastalar ile tek renal arterleri olan hastaların laboratuvar incelemeleri ve kan basıncı yükü açısından anlamlı bir fark yoktu. Takip süresi sonunda hedef organ hasarının sıklığı ve kullanılan ilaç sayısı da her iki grup için benzerdi.

Sonuç: Manyetik Rezonans Anjiyografi, aksesuar renal arteri saptamada Doppler Ultrasonografi görüntülemesi ile elde edilenden daha başarılıdır. Ancak, aksesuar renal arterlerin varlığının hastalığın prognozunu etkilemediği görülmektedir.

Anahtar Sözcükler: Çocuk, Hipertansiyon, Renal arter

\section{INTRODUCTION}

Renovascular hypertension was shown to be the cause of almost $10 \%$ of childhood hypertension (1). Although the prevalence of primary essential hypertension, mostly in older school-age children and adolescents has increased in parallel with the epidemic of obesity, renovascular diseases remain an important factor leading to hypertension in children. Vascular imaging in the diagnostic evaluation of children with hypertension should be considered once hypertension is confirmed. Initial radiological investigations may include Doppler renal ultrasound, 99mTc dimercaptosuccinic acid (DMSA), and followed by CTA or magnetic resonance angiography (2).

Accessory renal arteries are common in 30\% of individuals and originate mostly from the abdominal aorta (3). The casual relationship between accessory renal arteries and hypertension in children is not as definite as it is observed in renal artery stenosis. De Jong et al.(4) have addressed the association between accessory renal arteries and hypertension. Various hemodynamic and biochemical mechanisms have been identified to explain the relationship between accessory renal arteries and hypertension (5). Nevertheless, the role of the accessory renal artery is still not clear. This study aims to determine the importance of accessory renal arteries in the etiology of childhood hypertension and also to compare the performance of MRA and renal doppler ultrasound in regard of detecting accessory renal arteries.

\section{MATERIAL and METHODS}

Medical records of hypertensive patients admitted to an outpatient clinic of pediatric nephrology department, in a tertiary referral hospital, from January 1, 2015, to December 31, 2017, were retrospectively reviewed and patients who had evaluated with MRA for differential diagnosis of renovascular hypertension were selected. MRA performed the patients who had treated with more than one antihypertensive drug or who had a suspicion of renal artery stenosis or accessory renal artery on Doppler USG imaging. Patients who were admitted with malignant hypertension, syndromic patients, and patients with any chronic illness were excluded.
Patients' data regarding their age, body mass index (BMI), biochemical analysis of blood and urine, Thyroid stimulant hormone (TSH), free T4, renin and aldosterone levels, results of radiologic studies including abdominal USG and renal Doppler USG as well as renal MRA were recorded. Estimated glomerular filtration rates (eGFR) of hypertensive patients were calculated according to the Schwartz formula. Serum was collected for renin and aldosterone levels when the patient is in the supine position during 8:00 am. Renin and aldosterone levels were studied with the radioimmunoassay method. Clinical symptoms, number of anti-hypertensive medications, and results of ambulatory blood pressure monitoring (ABPM) were also recorded. Clinical characteristics of patients at the last visit, presence of endorgan damage, medications, renal function tests, were also recorded. ABPM was performed on all patients who were hypertensive on casual blood pressure measurements with an appropriate-sized cuff for arm circumference and carried out over 24 hours during the patient's routine workday. Blood pressure was measured every 30 minutes during daytime hours (8 am to $12 \mathrm{pm}$ ) and every 60 minutes during nighttime hours (12 pm to $8 \mathrm{am}$ ). Based on the ABPMs, we analyzed general $24 \mathrm{~h}$ systolic and diastolic blood pressure load (BPL), daytime (8 a.m.-12 p.m.) and nighttime (12 p.m.-8 a.m.) systolic and diastolic BP load, and the number of dipper or non-dipper patients. According to ABPM data diagnosis of hypertension is based on the presence of mean systolic blood pressure (SBP) and/or diastolic blood pressure (DBP) >95 percentile and SBP and/or DBP load > 25\% (6). Patients with a nocturnal fall > $10 \%$ of the nighttime values were accepted as "dippers" while, patients with a nocturnal fall $<10 \%$ of the nighttime values were accepted as "non-dippers" (7).

Digital subtraction angiography (DSA) was performed on the patients who had resistant hypertension despite two antihypertensives.

This study was conducted in accordance with the Declaration of Helsinki and was approved by the Clinical Research Ethics Committee No.2, Ankara City Hospital (07.04.2021-E2-21311).

\section{Statistical analysis}

SPSS v.16 was used for statistical analysis. $P<0.05$ was considered statistically significant. Student t test, Mann- 
Whitney $\mathrm{U}$ test and Chi-Square test were used for inter-group comparisons.

\section{RESULTS}

Three hundred and eight patients were referred to our pediatric nephrology clinic with the diagnosis and/or suspicion of hypertension in primary care. Forty-nine (16\%) of them were found to have had renal MRA because of hypertension that was resistant to treatment with a single agent and with no definable etiologic factor or who had abnormalities suggesting renal artery stenosis or accessory renal artery in Doppler USG. The mean age of patients was $15.3 \pm 2.6$ years (median: 16 years) and male/female (M/F) was 31/18. The demographic data and the results of laboratory analysis of blood were all given in Table I.

Among those 49 patients with hypertension, 25 of them (51\%) were found to have accessory renal arteries. The mean age of patients with accessory renal arteries was $14.8 \pm 2.6$ years (median: 15). Fifteen of them were males (M/F: 15/10). The mean follow-up time of hypertensive patients with accessory renal arteries is $29 \pm 2.8$ months and $23.2 \pm 3.1$ months for patients with a single renal artery $(p>0.05)$. The demographic data of patients with accessory renal arteries were given in Table I.

Table I: Demographic data and results of blood analysis of the study group, and 25 hypertensive patients with accessory renal arteries.

\begin{tabular}{|c|c|c|c|}
\hline & $(n=49)$ mean \pm SD & $(n=25)$ mean $\pm S D$ & p \\
\hline Age (years) & $15.3 \pm 2.6$ & $14.8 \pm 1.4$ & $>0.05$ \\
\hline BMI & $26.4 \pm 8.1$ & $25.6 \pm 7.4$ & $>0.05$ \\
\hline eGFR (mL/min/1.73 m²) & $129.4 \pm 35.7$ & $127.5 \pm 33.6$ & $>0.05$ \\
\hline Creatinine $(\mathrm{mg} / \mathrm{dL})$ & $0.78 \pm 0.11$ & $0.79 \pm 0.13$ & $>0.05$ \\
\hline $\mathrm{Na}(\mathrm{mmol} / \mathrm{L})$ & $137.4 \pm 3.6$ & $137.4 \pm 1.7$ & $>0.05$ \\
\hline $\mathrm{K}(\mathrm{mmol} / \mathrm{L})$ & $4.1 \pm 1.9$ & $4.2 \pm 0.9$ & $>0.05$ \\
\hline $\mathrm{Cl}(\mathrm{mmol} / \mathrm{L})$ & $102.8 \pm 2.8$ & $102.9 \pm 2.7$ & $>0.05$ \\
\hline WBC $(\mu \mathrm{L})$ & $7.7 \pm 1.9$ & $7.9 \pm 2.1$ & $>0.05$ \\
\hline $\mathrm{Hg}(\mathrm{g} / \mathrm{dL})$ & $14 \pm 1.5$ & $14 \pm 1.5$ & $>0.05$ \\
\hline PLT ( $\mu \mathrm{L})$ & $281 \pm 65$ & $283.4 \pm 59.6$ & $>0.05$ \\
\hline $\mathrm{TSH}(\mu \mathrm{IU} / \mathrm{Ml})$ & $1.89 \pm 0.9$ & $1.6 \pm 0.7$ & $>0.05$ \\
\hline f T4 (ng/dL) & $0.83 \pm 0.1$ & $0.84 \pm 0.1$ & $>0.05$ \\
\hline Renin (ng/ml/h) & $35.7 \pm 41$ & $38.1 \pm 49.3$ & $>0.05$ \\
\hline Aldosterone (ng/dL) & $223.7 \pm 165.5$ & $190.1 \pm 141.5$ & $>0.05$ \\
\hline
\end{tabular}

BMI: Body mass index; eGFR: Estimated glomerular filtration rate; Na: Sodium; K: Potassium; Cl: Chlorine; WBC: White blood cells; Hg: Hemogram; PLT: Platelet; TSH: Thyrotrophin-Stimulating Hormone; $\boldsymbol{f}$ T4: free T4

Table II: Results of 24-hour ABPM of patients with renal MR angiography.

\begin{tabular}{|c|c|c|c|c|c|c|c|c|c|c|}
\hline & \multirow[t]{2}{*}{$\mathbf{n}$} & \multicolumn{3}{|c|}{$\begin{array}{c}\text { General evaluation } \\
\text { mean } \pm S D\end{array}$} & \multicolumn{3}{|c|}{$\begin{array}{l}\text { Daytime } \\
\text { mean } \pm \text { SD }\end{array}$} & \multicolumn{3}{|c|}{$\begin{array}{l}\text { Nighttime } \\
\text { mean } \pm \text { SD }\end{array}$} \\
\hline & & MAP & SBPL & DBPL & MAP & SBPL & DBPL & MAP & SBPL & DBPL \\
\hline $\begin{array}{l}\text { Hypertensive children who } \\
\text { had MR angiography }\end{array}$ & 49 & $130 / 71$ & $55 \pm 23$ & $31 \pm 22$ & $135 / 75$ & $53 \pm 25$ & $29 \pm 20$ & $116 / 62$ & $50 \pm 20$ & $31 \pm 26$ \\
\hline $\begin{array}{l}\text { Hypertensive children with } \\
\text { accessory renal arteries }\end{array}$ & 25 & $128 / 71$ & $59 \pm 27$ & $35 \pm 24$ & $135 / 75$ & $58 \pm 27$ & $34 \pm 24$ & $115 / 63$ & $53 \pm 27$ & $33 \pm 27$ \\
\hline $\begin{array}{l}\text { Hypertensive children } \\
\text { without accessory renal } \\
\text { arteries }\end{array}$ & 24 & $131 / 71$ & $50 \pm 19$ & $27 \pm 19$ & $134 / 74$ & $48 \pm 21$ & $24 \pm 15$ & $117 / 61$ & $46 \pm 22$ & $29 \pm 25$ \\
\hline
\end{tabular}

MAP: Mean arterial pressure; SBPL: Systolic blood pressure load; DBPL: Diastolic blood pressure load 


\begin{tabular}{|c|c|c|c|}
\hline & \multicolumn{2}{|c|}{ MR Angiography } & \multirow{2}{*}{ Total } \\
\hline & SRA & ARA & \\
\hline $\begin{array}{l}\text { Doppler USG } \\
\text { SRA } \\
\text { ARA } \\
\text { Suspicion of ARA }\end{array}$ & $\begin{array}{r}15 \\
0 \\
9\end{array}$ & $\begin{array}{r}13 \\
5 \\
7\end{array}$ & $\begin{array}{r}28 \\
5 \\
16\end{array}$ \\
\hline Total & 24 & 25 & 49 \\
\hline
\end{tabular}

SR: Single renal artery; ARA: Accessory renal artery

Renin and aldosterone levels of all patients were within the normal range. Renin and aldosterone levels were not significantly different between the two groups.

Age, BMl, eGFR, creatinine, sodium, potassium, chloride, leukocyte, hemoglobin, platelet, TSH, free T4 levels also were not significantly differed between groups ( $p>0.05)$.

We have compared to groups in terms of ABPM and there was not any significant difference between groups $(p>0.05)$. The results of 24 -hour ABPM were given in Table II.

Except one patient with a rotational kidney anomaly; all patients had normal ultrasonographic examination. The DMSA scan of this patient revealed normal separate functions. Other patients had normal urinary tract USG.

Renal Doppler USG revealed a suspicion of the accessory renal artery in 16 patients. However, only the diagnosis of 7 patients was correlated with MRA. Despite the normal Doppler USG, 13 patients were found to have accessory renal artery with MRA (Table III).

Eighteen patients were found to have left ventricular hypertrophy $(\mathrm{LVH})$ and 9 patients have had hypertensive retinopathy. Nine of the patients $(50 \%)$ with LVH were among patients with accessory renal arteries. Five of the patients with hypertensive retinopathy (55\%) were found to have accessory renal arteries. The difference between the groups regarding the frequency of end-organ damage was not found to be statistically significant. Proteinuria was not detected in any of our patients.

The mean follow-up time of hypertensive patients with accessory renal arteries is $29 \pm 2.8$ months and $23.2 \pm 3.1$ months for patients with a single renal artery. During this time only 4 of them (16\%) underwent Digital subtraction Angiography (DSA) because of hypertension which was difficult to treat. All of the patients' DSA were normal.

No patient required surgical intervention. Five of 25 (20\%) patients with accessory renal artery and 8 of 24 (33\%) patients with a single renal artery were not receiving any antihypertensive drug at the last visit ( $p>0.05)$. Sixteen patients (64\%) with accessory renal arteries and 11 (45\%) patients with single renal artery were on treatment with a single antihypertensive drug ( $p>0.05)$. Four (16\%) patients with accessory renal arteries and
$5(20 \%)$ patients with single renal arteries were found to be treated with multiple drugs ( $p>0.05$ ). Eight (32\%) of patients with accessory renal arteries and 8 (33\%) of patients with a single renal artery had LVH at the last visit $(p>0.05)$. Two patients in both groups were found to have hypertensive retinopathy at the last control ( $p>0.05)$.

\section{DISCUSSION}

The renal arteries usually originate from the abdominal aorta. In general, each kidney receives a single renal artery (5). Different origins of renal arteries are the most frequent renal vascular anomaly in the general population (6). The frequency of extrarenal arteries reported as much as 35\% among the normal population $(3,7)$. In this study, we detected accessory renal arteries in $51 \%$ of hypertensive patients. Accessory renal arteries were found to be significantly more prevalent in our hypertensive patients compared to the normal population. We also found that accessory renal arteries were more frequently located on the left side which is convenient with the literature (5).

In terms of diagnosis, there are many types of imaging techniques, such as Doppler USG, Computed Tomography Angiography (CTA), MRA, and DSA $(1,8)$. Doppler USG is a widely available, noninvasive, repeatable, relatively inexpensive, and extremely safe imaging method for the measurement of renal blood flow. Moreover, Doppler USG does not have ionizing radiation. However, despite the use of multiple views, and the experience acquired with practice, accessory renal arteries as well as renal arterial stenosis can be missed by Doppler USG (1). In our study 13 patients who had had normal renal Doppler USG examination were detected to have accessory renal arteries on MRA (Table III). The possibility of detecting the accessory renal artery by renal Doppler USG was considerably lower than MRA.

It is claimed that the accessory renal artery increases the risk of developing hypertension (9). Paige VA et al.(3) have found that $59 \%$ of adult patients with resistant hypertension had accessory renal arteries compared to $32 \%$ of healthy transplant donors. More studies are confirming this association and proposing that accessory renal arterial stenosis may cause renal ischemia and renin-dependent hypertension $(3,9,10)$. Kem et al.(11) have hypothesized that hyperreninism results from inadequate vessel size. High plasma renin activity may accompany accessory renal artery and hypertension (10).

In our study we did not find any difference in terms of renin and aldosterone levels, between hypertensive patients who have an accessory or single renal artery. Glodny B. et al. (10), have shown that plasma renin response to furosemide stimulation in patients with multiple renal arteries was only slightly greater 
than the controls. However, in the same study, it was found that plasma renin activity was significantly higher in patients with multiple arteries. It also should be emphasized that they selected patients with imaging evidence of eccentric or concentric narrowing of the accessory renal artery by more than 30\% (10). Our results could be affected by antihypertensive medications of patients and/or technical difficulties in measuring plasma renin activity.

Accessory renal arteries usually do not have any impact on the function of the kidneys or any other clinical manifestation. In this study, no significant difference was found between the two groups in terms of renal function tests, serum levels of renin and aldosterone, and results of ABPM as well as estimated GFR. Surprisingly, blood pressure load did not differ between both groups and probably could not be used as a clue to predict the presence of accessory renal arteries. Regarding endorgan damage, we also did not find any difference between the groups. However, studies with a higher number of patients should be conducted to get more precise results.

Some adult studies are demonstrating that patients with multiple renal arteries have a significantly higher blood pressure than patients with normal renal anatomy $(3,7,9,10)$. However, the prognosis of those patients has not been studied well. In our study, we followed-up with our patients for approximately 2 years. At the end of 2 years of follow-up, we did not find any difference regarding the number of medications and frequency of end-organ damage. Five of our patients with accessory renal arteries are free of drugs and 16 of them are still treated with one antihypertensive drug at the end of 2 years. These results did not differ from patients with single renal arteries.

We also conclude that the prognosis of patients with accessory renal arteries is as good as those with a single renal artery. We wanted to draw attention to the fact that the role of renal Doppler USG is quite weak in the detection of the accessory renal artery. However, more evidence is needed to determine the impact of the accessory renal artery on hypertension. To detect the prognosis of the patients with accessory renal arteries and the need for surgical intervention prospective studies with a large number of patients are required.

\section{REFERENCES}

1. Tullus K, Brennan E, Hamilton G, Lord R, McLaren CA, Marks SD, et al. Renovascular hypertension in children. Lancet 2008;371:145363.

2. Marks DS, Tullus K. Update on imaging for suspected renovascular hypertension in children and adolescents. Curr Hypertens Rep 2012;14:591-5

3. Standring S, ed. Gray's Anatomy. The Anatomical Basis of Clinical Practice. 40th Ed., Edinburg, Churchill \& Livingstone 2008;1231-3.
4. de Jong MR, Hoogerwaard AF, Gal P, Adiyaman A, Jaap Jan J Smit, Peter Paul H M Delnoy, et al. Persistent increase in blood pressure after renal nerve stimulation in accessory renal arteries after sympathetic renal denervation. Hypertension 2016;67: 12117.

5. Satyapal KS, Haffejee AA, Singh B, Ramsaroop L, Roobs JV Kalideen JM. Additional renal arteries: incidence and morphometry. Surg Radiol Anat 2001;23:33-8.

6. Sinaiko AR, Gomez-Marin O, Prineas RJ. Prevalence of "significant" hypertension in junior high school- aged children: the Children and Adolescent Blood Pressure Program. J Pediatr 1989;114:664-9.

7. Verdecchia P. Prognostic value of ambulatory blood pressure. Current evidence and clinical implications. Hypertension 2000;35:844-51.

8. Flynn JT, Kaelber DC, Baker-Smith CM, Blowey D, Carrol AE, Daniels SR, et al. Clinical Practice Guideline for Screening and Management of High Blood Pressure in Children and Adolescents. Pediatrics 2017;140: e20171904.

9. Glodny B, Cromme S, Wortler K, Winde G. A possible explanation for the frequent concomitance of arterial hypertension and multiple renal arteries. Med Hypotheses 2001;56:129-33.

10. Glodny B, Cromme S, Reimer P, Lennarz M, Winde G, Vetter H. Hypertension associated with multiple renal arteries may be renindependent. J Hypertens 2000;18:1437-44.

11. Kem DC, Lyons DF, Wenzi J, Halverstadt D, Yu X. Renin-dependent hypertension caused by non-focal stenotic aberrant renal arteries: proof of a new syndrome. Hypertension 2005;46:380-5. 